\title{
Mothers' Knowledge and Reported Practice Regarding Inhalation Therapy for their Children Suffering from Croup
}

\section{Heba Mohamed Shaker ${ }^{1}$, Faten Shafik Mahmoud ${ }^{2}$ and Khadiga Mohamed Said ${ }^{3}$}

(1) (B.sc.in Nursing Science 2008), (Teacher in EL Fayoum Nursing School, 2013) (2) Professor of Pediatric Nursing, Faculty of Nursing-Benha University (3) Assistant Professor of Pediatric Nursing, Faculty of Nursing-Benha University

\begin{abstract}
Background: Croup is one of the most common causes of upper airway obstruction in young children. It is characterized by sudden onset of barky cough, hoarse voice, inspiratory stridor and respiratory distress caused by upper airway inflammation secondary to a viral infection. Mothers' Knowledge and Reporting Practice constitute a major factor in helping to achieve successful control of croup in children. Aim: assess mothers' knowledge and reported practice regarding inhalation therapy for their children suffering from croup. Design: A descriptive analytic design was used to accomplish this study. Settings: The study was carried out in inpatient units at pediatric department and outpatient pediatric clinic affiliated to Benha University Hospital and Benha Specialized Pediatric Hospital. Subjects: A convenient sample of 100 mothers accompanying their children with croup at previously mentioned settings. Tools of data collection: Two tools were used: Tool (1) Arabic Structured Interviewing Questionnaire Sheet including two parts: a) Mothers and children characteristics. b) Mother's knowledge about croup and inhalation therapy. Tool (2) Observational check lists, to assess mother's reported practice regarding inhalation therapy, physiotherapy and care of fever. Conclusion: More than half of the studied mothers had inadequate knowledge and unsatisfactory level of practice about croup and inhalation therapy .The low knowledge and incorrect practice of mothers mostly affected by residence (rural), low educational level of mother, age (less than 30 years and more than 40 years), occupational status (housewives) and dis attending training courses. The study recommended and emphasized the importance of: Improve the knowledge and practice of mothers' by provide adequate education to mothers' about croup cause, signs, symptoms, risk factors, complications and treatment with focus on inhalation therapy by encourage the role of media, nongovernmental organization and health workers .
\end{abstract}

Keywords: Croup, Mother's knowledge, Reported Practice, Inhalation therapy.

\section{Introduction}

Croup is known as laryngotracheobronchitis, it is a common childhood respiratory illness caused by a range of viruses. The term croup is used to describe a variety of respiratory illnesses in children. It mostly occurs in infants and young children between six months and three years of age and is less commonly seen in children older than six years. It is usually seen in the fall and early winter months. It is slightly more common in boys compared with girls. Viral infection causes inflammation of the upper airway, which is characterized by barking cough, inspiratory stridor, hoarseness and respiratory distress. Most cases of croup are 
relatively mild and self-limiting. However, croup can occasionally cause severe respiratory obstruction and rarely, death (Tyler et al., 2017).

The most common cause of croup is a viral infection such as Para influenza or influenza that leads to swelling of the larynx (voice box) and trachea (windpipe). However, infection with these viruses is common and most children with these infections do not develop croup. The viruses infect the nose and throat initially and then spread along the upper respiratory tract (back of the throat) to the larynx and trachea. As the infection progresses, the bottom part of the larynx and top part of the trachea become swollen, this narrows the space available for air to enter the lung. Bacterial infection of the same areas can occur during the viral infection, but this does not happen very often. Bacterial infection is usually more severe and requires a different treatment than a viral infection (Banga et al., 2017).

Inhalation therapies are a group of respiratory, or breathing, treatments designed to help restore or improve breathing function in infants with a variety of diseases, conditions, or injuries. There are two main ways inhaled medicine is used: with an inhaler, and with a nebulizer. Inhalers and nebulizers have the same purpose: to get the medicine into your lungs. Both deliver the same type of medicine, and they work equally well when you use them properly (Ackley et al., 2019).

Treatments at home of mild croup include; allowing the child to breathe cool air during the night by opening a window or door. Fever can be treated with an over-the-counter medication such as acetaminophen or ibuprofen. Coughing can be treated with warm, clear fluids to loosen mucus on the vocal cords. Warm water, apple juice, or lemonade is safe for children older than four months. Frozen juice popsicles also can be given. Smoking in the home should be avoided; smoke can worsen a child's cough. Keep the child's head elevated. A child may be propped up in bed with an extra pillow. Pillows should not be used with infants younger than 12 months of age. Parents may sleep in the same room with their child during an episode of croup so that they will be immediately available if the child begins to have difficulty breathing (Hockenberry \& Wilson, 2018).

Nurses' role for children suffering from croup depends upon the type and severity of signs and symptoms but may include one or more of the following; humidified air or oxygen (if oxygen is necessary). IV fluids may be needed if the child is dehydrated as a result of fever or rapid breathing, both of which increase the body's loss of fluids. Difficulty breathing can discourage a child from drinking, which can increase the risk of dehydration. Monitoring of oxygen levels, breathing and heart rate, skin color, and level of alertness are used to measure the child's status and response to treatment. A child who fails to improve or who improves slowly may need further treatment (Al Otaibi \& Al Ateeq, 2018).

\section{Significance of the study}

Croup is the most common pediatric illness that causes severe breathing difficulties, stridor, atelectasis and swelling of epiglottis, croup accounting for approximately $15 \%$ of annual clinic and emergency department visits for pediatric respiratory tract infections. The number of cases of croup disease attributed to 


\section{Heba Mohamed Shaker, Faten Shafik Mahmoud and Khadiga Mohamed Said}

clinics and emergency Benha University Hospital was 35 cases episode/200 child-week infected with respiratory infection (Benha University Hospital Statistical Department 2019). Moreover, the number of cases of croup disease attributed to clinics and emergency Benha Children Specialist Hospital was 40 cases per week out of 200 cases infected with respiratory infection (Benha Specialized Pediatric Hospital Statistical Department 2019).

It is important to understand more about care of children with croup to improve the care provided for these children. The child with croup is vulnerable to emotional and behavior problems leading to poor quality their lives. It also may affect social relation, child interaction, and self-esteem. So, a great attention should be taken especially by mothers during follow up and treatment.

\section{Aim of the study}

This study aimed to assess mothers' knowledge and reported practice regarding inhalation therapy for their children suffering from croup.

\section{Research questions}

- What were the levels of mothers' knowledge regarding inhalation therapy for their children suffering from croup?

- What were the levels of mothers' reported practice regarding inhalation therapy for their children suffering from croup?

\section{Subject and Methods}

\section{Technical design:}

The technical design included research design, setting, subjects as well as tools of data collection.

\section{Research Design:}

Descriptive design was used to accomplish this study.

\section{Research Settings:}

The current study was carried out in inpatient at pediatric department and outpatient pediatric clinic affiliated to Benha University Hospital and Benha Specialized Pediatric Hospital.

\section{Research Subjects:}

A convenient sample (100) mothers accompanying their children suffering from croup from the above mentioned settings were selected regardless of their characteristics and willing to participating in the study.

Data was collected; through the following two tools:

\section{Tool (I): A structured Interviewing Questionnaire:}

It was designed by the researcher after reviewing related literatures, web sites, journals and text books and it was reviewed by supervisors. It was written in an Arabic language for gathering data to suit the understanding level of the study subject. It entails two parts as the following:

\section{Part (I):}

A: Personal characteristics of mothers which include age, occupational, level of education, social status, the number of family members , number of rooms, are there windows in each room, Place of residence, training course on how to care for your child. 
B: Personal characteristics of children which include age, gender, ranking, previous hospitalization, history of respiratory infection, Current Weight.

\section{Part (II):}

The questioner consisted of 36 questions and is divided into two parts:

A: First part knowledge of mother about respiratory system and croup disease: It includes (22) multiple choice question related to Components of the upper respiratory tract, Components of the lower respiratory tract, definition of croup, causes, symptoms, complication and care as well as source of information. It was adapted by the researcher based on (Duderstadt, 2017; Hockenberry \& Wilson, 2018).

B: Second part knowledge of mother about respiratory system and croup disease: It includes (14) multiple choice questions related to inhalation therapy for children suffering from croup such as definition, causes, indication, complication and care. It was adapted by the researcher based on (Wilson \& Rodgers, 2016;

Fuhrman \& Zimmerman, 2016).

\section{Scoring system:}

A scoring system was followed to assess Mothers' knowledge related to croup and inhalation therapy for children. The Questionnaire was contained of (36) questions, the total scores of the questionnaire were 68 grades, the right complete answer was scored (2), the right incomplete answer was scored (1) and the wrong answer or don't know answer was scored (0). These scores were summed and were converted into a percent score.
It was classified into 3 categories:

- Good knowledge if score $\geq 75 \%$.

- Average knowledge if score from 50 $75 \%$.

- Poor knowledge if score $<50 \%$.

Tool II. Mothers' Reported Practice (MRP):

It was adapted from James, Nelson, \& Ashwill, (2014); Wilmott et al., (2018); Fonceca, Ditcham, Everard, \& Devadason, (2019) and it revised by supervisors. It was used to assess mothers' reported practice regarding inhalation therapy for children suffering from croup. It included 65 steps which the following observation checklists related to care of nebulizer apparatus (8), inhalation drug administration (18), care of fever (7), bulb suction (4), Nebulizer inhalation technique(9), Chest physiotherapy (9).

\section{Scoring system:}

A scoring system was used to assess a mothers' reported practice; each checklist was assigned a score according to sub-items. The total score of reported practice were 65 grades, each item was evaluated as "yes" was taken (1) score and "No" was taken (0) score. These scores were summed up and were converted into a percentage score. It was classified into 2 categories:

- $\quad$ Satisfactory reported practice if score $\geq$ $60 \%$.

- Unsatisfactory reported practice if score $<60 \%$. 


\section{Reliability}

Reliability of the tools was applied by measuring of internal consistency of the tool through Cronbach's alpha coefficient test.

\begin{tabular}{|l|c|}
\hline \multicolumn{1}{|c|}{ Tool } & $\begin{array}{c}\text { Cronbach's } \\
\text { Alpha }\end{array}$ \\
\hline $\begin{array}{l}\text { A structured Interviewing } \\
\text { Questionnaire }\end{array}$ & .798 \\
\hline Mothers' reported practice & .763 \\
\hline
\end{tabular}

\section{Statistical design:}

The data collected were revised, coded, tabulated and statistically analyzed using statistical package for the social science (SPSS) version 20 for windows and running on IBM compatible computer. Results were presented by tables and graphs. Descriptive statistics were applied (e.g. frequency, percentages, mean with standard deviation) and chi-square $\left(\mathrm{X}^{2}\right)$ was used to examine the significance between qualitative variables. Reliability of the study tools was done using Cronbach's Alpha coefficient. A significant level value was considered when $\mathrm{p}<0.05$ and a highly significant level value was considered when $\mathrm{p}<$ 0.001 . No statistical significance difference was considered when $\mathrm{p}>0.05$.

\section{Results}

Figure (1) demonstrates that $58 \%$ of the studied mothers had poor level of total knowledge about croup and inhalation therapy. Also, 24\% of them had average level of total knowledge. In addition $18 \%$ of them had good level of total knowledge.

Figure (2) illustrates that $75 \%$ of the studied mothers had unsatisfactory level of total practice regarding croup and inhalation therapy. In addition $25 \%$ of them had satisfactory level of total practice.

Table (1) reveals that there were highly statistically significant relation between total knowledge about croup and inhalation therapy of the studied mothers and their level of education, job and mother class at $(\mathrm{P}=<0.01)$. Also, there were statistically significant relation with their age and residence at $(\mathrm{P}=<0.05)$. While, there were no significant relation with marital status at $(\mathrm{P}=>0.05)$.

Table (2) shows that there were highly statistically significant relation between total practice regarding croup and inhalation therapy of the studied mothers and their level of education and mothers class at $(\mathrm{P}=<0.01)$. Also, there were statistically significant relation with their age, job and residence at $(\mathrm{P}=<0.05)$. While, there were no significant relation with marital status at $(\mathrm{P}=>0.05)$.

Table (3) illustrates that there was highly statistically positive correlation between total knowledge of the studied mothers and their total practice regarding croup and inhalation therapy. 


\section{Total knowledge}

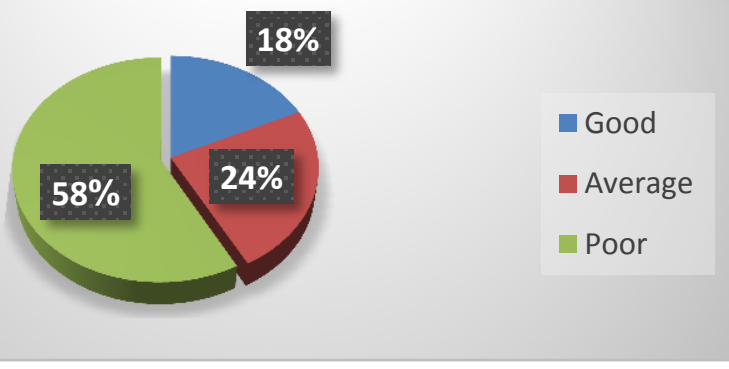

Figure (1): Percentage distribution of the studied mothers according to their total knowledge $(n=100)$.

\section{Total practice}

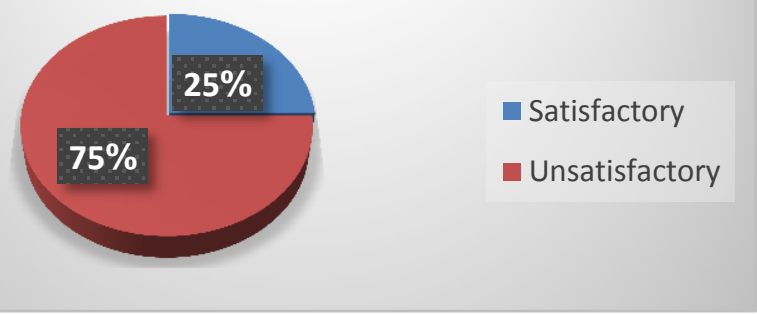

Figure (2): Percentage distribution of the studied mothers according to their total practice $(n=100)$.

Table (1): Relation between demographic characteristics of the studied mothers and their total knowledge about croup and inhalation therapy.

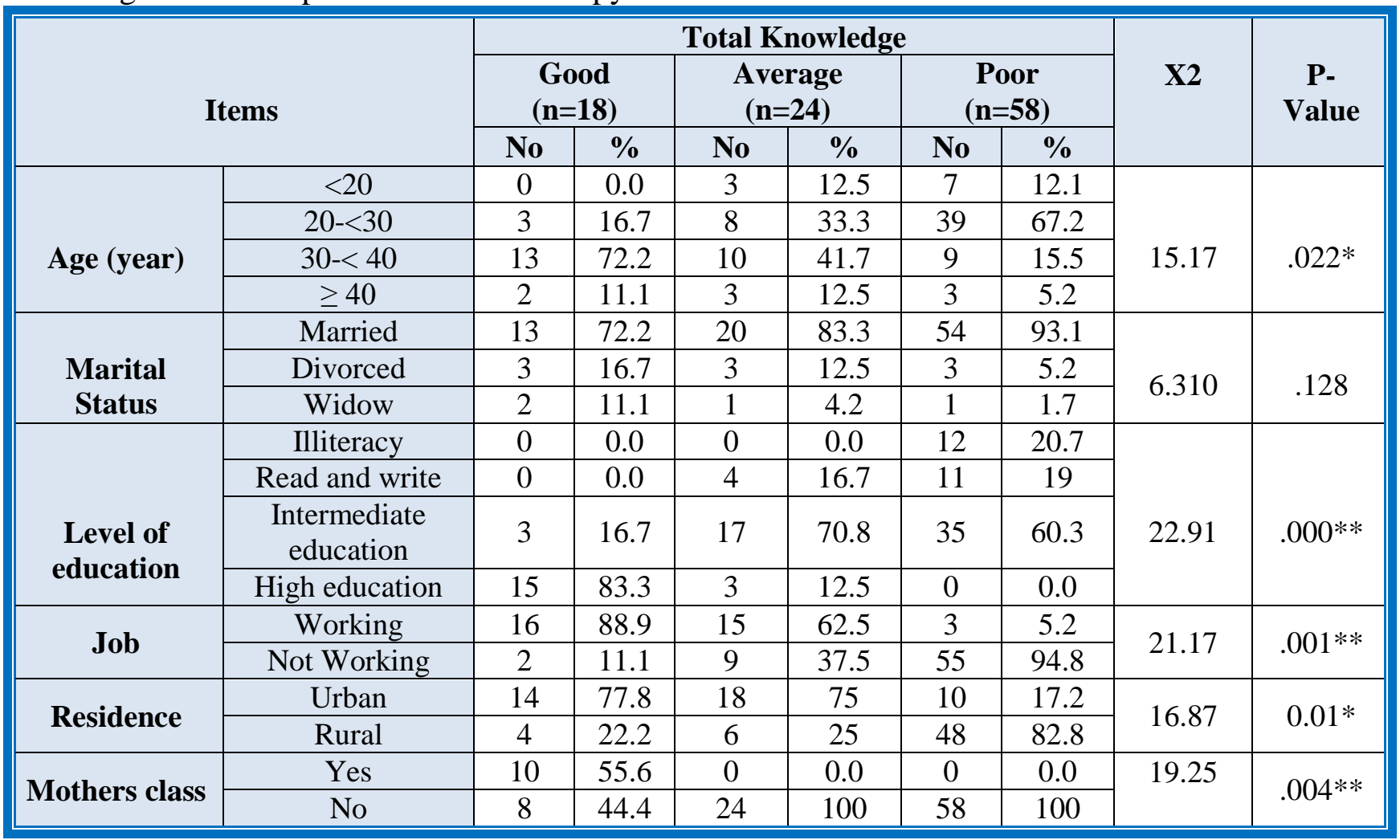

$*$ significant at $p<0.05 . * *$ highly significant at $p<0.01$. 
Heba Mohamed Shaker, Faten Shafik Mahmoud and Khadiga Mohamed Said

Table (2): Relation between demographic characteristics of the studied mothers and their total practice about croup and inhalation therapy.

\begin{tabular}{|c|c|c|c|c|c|c|c|}
\hline \multirow{3}{*}{\multicolumn{2}{|c|}{ Items }} & \multicolumn{4}{|c|}{ Total practice } & \multirow{3}{*}{$\mathbf{X} 2$} & \multirow{3}{*}{$\begin{array}{c}\text { P- } \\
\text { Value }\end{array}$} \\
\hline & & \multicolumn{2}{|c|}{$\begin{array}{l}\text { Satisfactory } \\
\quad(n=25)\end{array}$} & \multicolumn{2}{|c|}{$\begin{array}{l}\text { Unsatisfactory } \\
\qquad(\mathbf{n}=75)\end{array}$} & & \\
\hline & & No & $\%$ & No & $\%$ & & \\
\hline \multirow{4}{*}{ Age (year) } & $<20$ & 3 & 12 & 7 & 9.3 & \multirow{4}{*}{14.12} & \multirow{4}{*}{$0.031 *$} \\
\hline & $20-<30$ & 5 & 20 & 45 & 60 & & \\
\hline & $30-<40$ & 15 & 60 & 17 & 22.7 & & \\
\hline & $\geq 40$ & 2 & 8 & 6 & 8 & & \\
\hline \multirow{3}{*}{$\begin{array}{l}\text { Marital } \\
\text { Status }\end{array}$} & Married & 20 & 80 & 67 & 89.3 & \multirow{3}{*}{7.692} & \multirow{3}{*}{0.112} \\
\hline & Divorced & 3 & 12 & 6 & 8 & & \\
\hline & Widow & 2 & 8 & 2 & 2.7 & & \\
\hline \multirow{4}{*}{$\begin{array}{l}\text { Level of } \\
\text { education }\end{array}$} & Illiteracy & 0 & 0.0 & 12 & 16 & \multirow{4}{*}{24.54} & \multirow{4}{*}{$.000 * *$} \\
\hline & Read and write & 0 & 0.0 & 15 & 20 & & \\
\hline & $\begin{array}{c}\text { Intermediate } \\
\text { education }\end{array}$ & 7 & 28 & 48 & 64 & & \\
\hline & High education & 18 & 72 & 0 & 0.0 & & \\
\hline \multirow{2}{*}{ Job } & Working & 21 & 84 & 13 & 17.3 & \multirow{2}{*}{13.21} & \multirow{2}{*}{$0.036 *$} \\
\hline & Not Working & 4 & 16 & 62 & 82.7 & & \\
\hline \multirow{2}{*}{ Residence } & Urban & 22 & 88 & 20 & 26.7 & \multirow{2}{*}{12.98} & \multirow{2}{*}{$0.04 *$} \\
\hline & Rural & 3 & 12 & 55 & 73.3 & & \\
\hline \multirow{2}{*}{$\begin{array}{l}\text { Mothers } \\
\text { class }\end{array}$} & Yes & 10 & 40 & 0 & 0.0 & \multirow[t]{2}{*}{21.25} & \multirow{2}{*}{$.001 * *$} \\
\hline & No & 15 & 60 & 75 & 100 & & \\
\hline
\end{tabular}

*significant at $\mathrm{p}<0.05$. **highly significant at $\mathrm{p}<0.01$.

Table (3): Correlation between total knowledge of the studied mothers and their total practice regarding croup and inhalation therapy.

\begin{tabular}{|c|c|c|}
\hline \multirow{2}{*}{ Item } & \multicolumn{2}{|c|}{ Total practice } \\
\cline { 2 - 3 } & $\mathrm{R}$ & $\mathrm{P}$-value \\
\hline Total knowledge & 0.391 & $.000 * *$ \\
\hline
\end{tabular}

(**) Statistically significant at $\mathrm{p}<0.05$. 


\section{Discussion}

Concerning total knowledge about croup and inhalation therapy, the finding of the current study revealed that more than half of the studied mothers had poor level of total knowledge about croup and inhalation therapy. Also, slightly less than one quarter of them had average level of total knowledge. While, slightly less than one fifth of them had good level of total knowledge. This bad level of knowledge could be explained by the high rate of false beliefs that are spread around the disorder, likewise the misinterpretation and misconceptions of the signs and symptoms of illness. Another explanation might be due to the lack of right and specific information about the disease on media such as television, newspapers, magazines, and etc. Furthermore, there is shortage in the health services that introduce health education for family and parents; the health services predominantly interested in giving medical care.

These results similar with the results of Nadhem, R., Mohammed, N., \& Hundhal, (2018) who study was about "Assessment of Mother's Knowledge Concerning Recurrent Wheezy Chest among Children under Age five years old" and indicated that about half of the mothers had poor level of knowledge.

But the present study is inconsistent with Enggar, \& Pont, (2018) who study was about The Relationship of Knowledge and Attitudes of the Mother Have a Children of Incidence Acute Respiratory Infection, and stated that three quarters of the studied sample were well knowledgeable.
Concerning women's total practice regarding croup and inhalation therapy, the finding of the current study revealed that three quarters of the studied mothers had unsatisfactory level of total practice regarding croup and inhalation therapy. While, one quarter of them had satisfactory level of total practice. These results mean that the mothers' knowledge had an effect on their practices, as when the mothers have unsatisfactory knowledge level regarding their children conditions; this will affect their practices regarding care of their children with croup and inhalation therapy. These results similar with the results of Farhad et al., (2014) and Abdalla, (2017) who studies were about Knowledge, Attitude and Practices of Parents of Asthmatic Children about Asthma and stated that two thirds of the studied sample had unsatisfactory level of total practice. But the present study is inconsistent with the study of Al-Ali et al., (2019) who reported that less than two thirds of the studied women had good level of total practice.

\section{Regarding to correlation between total} knowledge of the studied mothers and their total practice regarding croup and inhalation therapy, the present study revealed that there was highly statistically positive correlation between total knowledge of the studied mothers and their total practice. This could be explained as good level of knowledge among women was more encountered among those women with satisfactory level of practice. This result agreed with the result of Joshy et al., (2018) who study was about Effectiveness of Information Booklet on Knowledge of Mothers Regarding Home Management of Respiratory Tract Infection among Under Five Children and stated that total knowledge of the 
studied mothers had a significant effect on their total practice.

\section{According to relation between} demographic characteristics of the studied mothers and their total knowledge about croup and inhalation therapy, the present study revealed that there were highly statistically significant relation between total knowledge of the studied mothers and their level of education, occupation and training course. Also, there were statistically significant relation with their age and residence. This could be explained as, poor level of knowledge were higher among women with age group between $20-<30$ year and residing in rural areas. Also, it seems that, whenever the women had high education, working and attending training courses, the total knowledge score increased. This result agreed with the result of AboElkheir, Hafez, \& Mohamed, (2016) who study was about Environmental and Personal Factors Related to Asthma Severity among Children and found that there was high statistically significant relation between total knowledge score of the studied sample and their age, educational level and place of resident.

But these results disagreed with the results of Naz et al. (2015) who study was about Educational interventions for cervical cancer screening behavior of women, who stated that level of education and attendance of training course had a significant effect on mothers knowledge. Also, Abutiheen et al., (2019) stated that there was statistically significant relation between total knowledge of the studied mothers and their age, job and residence.

Regarding the relation demographic characteristics of the studied mothers and their total practice about croup and inhalation therapy, the present study showed that there was highly statistically significant relation between total practice of the studied mothers and their level of education and training course. Also, there was statistically significant relation with their age, occupation and residence. This could be explained as, satisfactory level of practice were higher among women with high education and attending training courses. Also, satisfactory level of practice was higher among women with age group between $30-<40$ year and residing in urban areas. These results agreed with the results of Fawcett, Porritt, Campbell, \& Carson, (2017) who studied Experiences of parents and careers in managing asthma in children and found that there was statistically significant relation between total practice of the studied mothers and their level of education and training course.

But these results disagreed with the results of Silva, Reyna, Wakida, Limón, \& Campos, (2018) who study was about Wheezing Disorders in Childhood and stated that there was no statistically significant relation between total practice of the studied mothers and their age and residence.

In the present study, there was no statistically significant relation between total knowledge and reported practice score of the studied women and their marital status. It seems that, there was no difference between woman's ' marital status to total knowledge and reported practice about croup and inhalation therapy. This result supported with the study performed by Vogelberg, (2019) about Preschool children with persistent asthmatic symptoms and mentioned that there was no statistically significant relation between total knowledge 
score of the studied sample and their marital status. In the same field, Bham et al., (2019) revealed that there was no difference between woman's' marital status to total about inhalation therapy.

Regarding to correlation between total knowledge of the studied mothers and their total practice regarding croup and inhalation therapy, the present study revealed that, there was highly statistically positive correlation between total knowledge of the studied mothers and their total practice. This could be explained as good level of knowledge among women was more encountered among those women with satisfactory level of practice. This result supported with the result of Joshy et al., (2018) who study was about Effectiveness of Information Booklet on Knowledge of Mothers Regarding Home Management of Respiratory Tract Infection among fewer than five children and stated that total knowledge of the studied mothers had a significant effect on their total practice.

\section{Conclusion}

\section{From our study we concluded that:}

More than half of the studied mothers had poor level of knowledge and two third of them had unsatisfactory level regarding the total reported practice and there was a highly statistically positive correlation between total knowledge and total reported practice.

\section{Recommendations}

\section{From this study we recommend that:}

1. In service training program for mothers' to improve their knowledge and reported practice about croup at outpatient clinics and hospitals for mothers.
2. Simple educational pamphlets and posters about croup should be provided for all mothers in outpatient clinics.

3. Further studies should be conducted on large sample of mothers to confirm out results.

\section{References}

Ahmed, D. (2016). Stressors and coping patterns of mothers having children with bronchial asthma. Master Thesis, Faculty of Nursing, Ain Shams University. p. 110.

Al-Ali, L., Al Jasmi, S., Al Yammahi, L., Syeed, A., \& Darwish, E. (2019). Parental knowledge, attitudes, and practices regarding the use of prescribed inhalers in asthmatic children attending Ambulatory Healthcare Services Clinics. Ibnosina Journal of Medicine and Biomedical Sciences, 11(2), 68.

AlOtaibi, E., \& AlAteeq, M. (2018).Knowledge and practice of parents and guardians about childhood asthma at King Abdulaziz Medical City for National Guard, Riyadh, Saudi Arabia. Risk management and healthcare policy, 11, 67.

Banga, S., Tali, S. H., Singh, P., Yousuf, S., Singh, K., Pannu, M. S., \& Malik, G. (2017). Study the knowledge of asthma in mothers of children suffering from wheezing disorders. Steroids, 10, 12-8.

Duderstadt, K. (2017). Pediatric Physical Examination-E-Book: An Illustrated Handbook. Elsevier Health Sciences.

Ebrahim, N. (2017). Nursing intervention for school age children with bronchial asthma in a rural area. Unpublished Doctorate 
Thesis, Faculty of Nursing, Ain Shams University. pp. 33, 89, 94

Abdalla, W. (2017). Knowledge, Attitude and Practices of Parents of Asthmatic Children about Asthma in Elwehda village in South of Gezira Locality, Gezira State, Sudan (2017) (Doctoral dissertation, University of Gezira).

Abdel-Baseer, K., Hammad, E., Qubaisy, H., Naser, M., Ahmed, A., \& Said, A. (2017). Some epidemiological aspects of bronchial asthma in children in Qena Governorate, Egypt. Immunome Research, 13(3), 1-5.

Ackley, B. J., Ladwig, G. B., Msn, R. N., Makic, M. B. F., Martinez-Kratz, M., Z anotti, M. (2019). Nursing Diagnosis Handbook E-Book: An Evidence- Based Guide to Planning Care. Mosby.

Banga, S., Tali, S. H., Singh, P., Yousuf, S., Singh, K., Pannu, M. S., \& Malik, G. (2017). Study the knowledge of asthma in mothers of children suffering from wheezing disorders. steroids, 10, 12-8.

Duderstadt, K. (2017). Pediatric Physical Examination-E-Book: An Illustrated Handbook. Elsevier Health Sciences.

Ebrahim, N. (2017). Nursing intervention for school age children with bronchial asthma in a rural area. Unpublished Doctorate Thesis, Faculty of Nursing, Ain Shams University. pp. 33, 89, 94

El-Morshedy, S. (2014). Quality of life for children suffering from bronchial asthma. Unpublished Master Thesis, Faculty of Nursing, Ain Shams University. p. 16.

Enggar, E., \& Pont, A. (2018). The Relationship of Knowledge And Attitudes Of The Mother Have A Children Of Incidence Acute Respiratory Infection
(ARI) In Tinggede Health Center Care. In PROSIDING Seminar Nasional Tahun 2018 ISBN: 2549-0931 (Vol. 1, No. 3, pp. 550-558).

Farhad, J., Malihe, A., Fatemeh, A., \& Mahmood, S. (2014). The knowledge, attitude and practice of mothers regarding acute respiratory tract Infection in children. Biosci Biotech Res Asia, 11(1), 343-348.

Fonceca, A., Ditcham, W., Everard, M., \& Devadason, S. (2019). Drug administration by inhalation in children. In Kendig's Disorders of the Respiratory Tract in Children (pp. 257-271). Content Repository Only!.

Fuhrman, B., \& Zimmerman, J. (2016). Pediatric Critical Care E-Book. Elsevier Health Sciences.

Glick, A., Farkas, J., Nicholson, J., Dreyer, B., Fears, M., Bandera, C., \& Yin, $H$. (2017). Parental management of discharge instructions: a systematic review. Pediatrics, 140(2).

Hassan, S., Esmat, O., \& Mohamed, H. (2018). Discharge Plan for Mothers to Cope with their Children Suffering from Bronchial Asthma. IOSR Journal of Nursing and Health Science 7, (2): 24-37.

Hickey, A. J., \& Mansour, H. M. (2019).Inhalation aerosols: physical and biological basis for therapy (Vol. 1). CRC press.

Hockenberry, M. J., \& Wilson, D. (2018).Wong's nursing care of infants and children-E-book. Elsevier Health Sciences.

Hockenberry, M., \& Wilson, D. (2018). Wong's nursing care of infants and 
children-E-book. Elsevier Health Sciences.

James, S., Nelson, K., \& Ashwill, J. (2014). Nursing care of children-E-book: principles and practice. Elsevier Health Sciences.

Joshy, A., Baisel, A., Francis, A., Baiju, B. M., Oustrin, L., \& Jayims, B. K. (2018). Effectiveness of Information Booklet on Knowledge of Mothers Regarding Home Management of Respiratory Tract Infection among Fewer than Five Children in Pallithottam at Kollam. Asian Journal of Nursing Education and Research, 8(1), 167-172.

Joshy, A., Baisel, A., Francis, A., Baiju, B., Oustrin, L., \& Jayims, B. (2018). Effectiveness of Information Booklet on Knowledge of Mothers Regarding Home Management of Respiratory Tract Infection among Under Five Children in Pallithottam at Kollam. Asian Journal of Nursing Education and Research, 8(1), 167-172.

Moawad, E., Haron, M., Maher, R., Abdallah, E., Hussein, H., Badawy, N., \& ElRheem, M. (2017). Cross-sectional evaluation of the Bronchitis Severity Score in Egyptian children: A move to reduce antibiotics. South African Medical Journal, 107(4), 342-345.

Mohammed, A., \& Abou Zed, S. (2018). The Impact of an Educational Program on Mothers' Knowledge of Preventing Bronchiolitis for Their Children under Two Years. IOSR Journal of Nursing a nd Health Science (IOSR-JNHS.

Nadhem, R., Mohammed, N., \& Hundhal, A. (2018). Assessment of Mother's Knowledge Concerning Recurrent
Wheezy Chest among Children under Age five years old at AL-Hilla Hospitals/Iraq. Journal of Pharmaceutical Sciences and Research, 10(1), 114-117.

Sivamani, M. (2016). A study on health seeking behavior among mothers with acute respiratory infections in under-five children in a rural area of Coimbatore (Doctoral dissertation, PSG Institue of Medical Sciences and Research,

Wilmott, R., Bush, A., Deterding, R., Ratjen, F., Sly, P., Zar, H., \& Li, A. (2018). Kendig's Disorders of the Respiratory Tract in Children E-Book. Elsevier Health Sciences.

Wilson, D., \& Rodgers, C. (2016). Wong's essentials of pediatric nursing-e-book. Elsevier Health Sciences. 


\section{مطلومات وممارسات الأمهات عن العلاج بالإستنشاق لاى أطفالهن الذين يعانون من الخناق}

\section{هبه محمد شاكر - فاتن شفيق محمودـ خديجة محمد سعيد}

يعرف الخناق بأنـه مرض تنفسي شـائع بين الأطفال نـاجم عن مجموعـة من الفيروسـات ويتميز

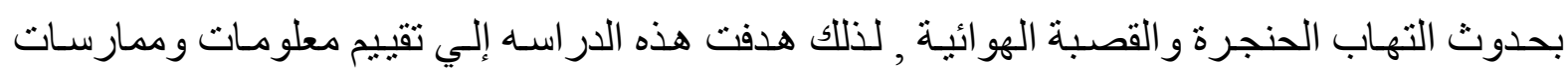
الأمهات عن العلاج بالإستنشاق لاى أطفالهن الذين يعانون من الخناق. وقد أجريت الدراسه في الوحدات

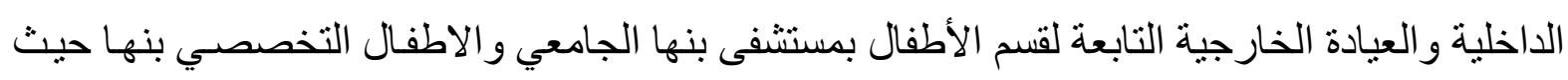

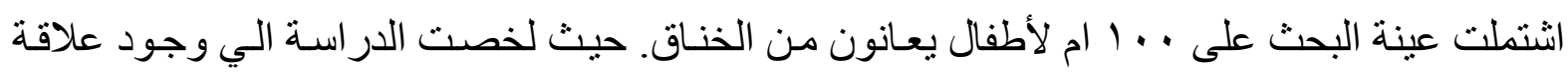

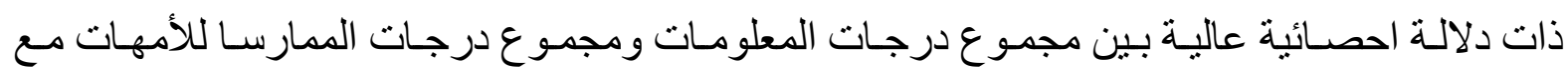

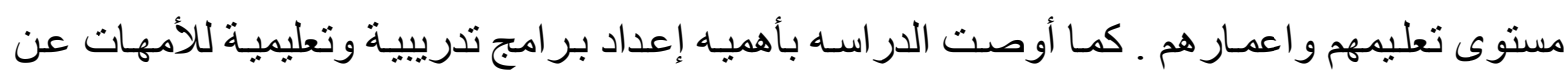
التعامل مع مرض الخناق ور عاية الطفل المصاب و الاستخدام الأمثل للعلاج الإستنشاقي. 